\title{
Methane Oxidation Biosystem In Landfill Fugitive Emissions Using Conventional Cover Soil And Compost As Alternative Substrate - A Field Study
}

\section{Yankha Myllena da Silva Van Tienen}

UNICENTRO: Universidade Estadual do Centro-Oeste

Gabriel Menon de Lima

UNICENTRO: Universidade Estadual do Centro-Oeste

Douglas Luiz Mazur

UNICENTRO: Universidade Estadual do Centro-Oeste

Kelly Geronazzo Martins

UNICENTRO: Universidade Estadual do Centro-Oeste

Erivelton César Stroparo

UNICENTRO: Universidade Estadual do Centro-Oeste

Waldir Nagel Schirmer ( $\nabla$ wanasch@hotmail.com )

UNICENTRO: Universidade Estadual do Centro-Oeste https://orcid.org/0000-0001-9475-3588

\section{Research Article}

Keywords: Atmospheric pollution, Bio-based cover systems, Biogas, Greenhouse gases, Solid waste valorization.

Posted Date: June 1st, 2021

DOI: https://doi.org/10.21203/rs.3.rs-276814/v1

License: (c) (i) This work is licensed under a Creative Commons Attribution 4.0 International License. Read Full License

Version of Record: A version of this preprint was published at Clean Technologies and Environmental Policy on August 9th, 2021. See the published version at https://doi.org/10.1007/s10098-021-02179-9. 


\section{Abstract}

Landfill is an important anthropogenic source of greenhouse gases (GHG). Aiming at methane mitigation through the use of a cover layer in the form of fugitive emissions, this study investigated the methane passive bioxidation in a Brazilian landfill in biofilters under two conditions: control column (packing material using a $60 \mathrm{~cm}$ landfill cover soil with $\cong 0.8 \%$ organic matter) and enriched column (packing material using $45 \mathrm{~cm}$ landfill cover soil and $15 \mathrm{~cm}$ mixture of cover soil plus compost with $\cong 6 \%$ organic matter). The biogas was collected from a vertical drain pipe of a four-year-old cell and injected into the base of the columns with a high inlet loading $\left(1000 \mathrm{~g} \mathrm{CH} 4 . \mathrm{m} \mathrm{-}^{2} \cdot \mathrm{d}-^{-1}\right.$ at standard temperature and pressure conditions) in the upward flow mode. Ten campaigns were carried out for six months in order to determine the efficiency of the methane oxidation in each column. Parameters related to the biogas oxidation were also determined, such as soil temperature and moisture content and nutrients content in both filter beds. The oxidation global efficiencies were higher in the enriched column throughout all campaigns, with »71 and $» 95 \%$ for the control and enriched columns, respectively. Our study demonstrated that the use of substrates with high organic matter content and low cost (such as the compost) in landfill cover layers might present high efficacy in the reduction of methane fugitive emissions. Landfill is an important anthropogenic source of greenhouse gases (GHG). Aiming at methane mitigation through the use of a cover layer in the form of fugitive emissions, this study investigated the methane passive bio-oxidation in a Brazilian landfill in biofilters under two conditions: control column (packing material using only landfill cover soil with $\cong 0.8 \%$ organic matter) and enriched column (packing material using $45 \mathrm{~cm}$ landfill cover soil and $15 \mathrm{~cm}$ mixture of cover soil plus compost with $\cong 6 \%$ organic matter). Biogas was collected from a vertical drain pipe of a four-year-old cell and injected into the base of the columns with a high inlet loading $\left(1000 \mathrm{gCH} 4 . \mathrm{m}^{-2} \cdot \mathrm{d}^{-1}\right)$ in upward flow mode. Ten campaigns were carried out for six months in order to determine the efficiency of the methane oxidation in each column. Soil temperature, moisture and nutrients content in both filter beds were also determined. The oxidation global efficiencies were higher in the enriched column throughout all campaigns, with $\gg 71$ and $\gg 95 \%$ for the control and enriched columns, respectively, demonstrating that this technology can be applied even in landfills where there is no energy recovery from biogas (as in most landfills in developing countries). Our study demonstrated that the use of substrates with high organic matter content and low cost in landfill cover layers might present high efficacy in the reduction of methane fugitive emissions. Even operating in field-scale conditions, the results of this study were comparable to those obtained with biofilters on lab-scale (under controlled operational conditions).

\section{Introduction}

In Brazil, as well as in other developing countries, landfills are still the main destination of municipal solid wastes (MSW). Despite being considered a proper destination from the technical and environmental standpoint, the anaerobic degradation of waste disposed in landfills promotes the formation of liquid (leachate) and gaseous (biogas) byproducts. Biogas is mainly composed of methane and carbon dioxide; although they are both greenhouse effect precursors, methane presents a global warming potential (GWP) 21 times higher than that of the carbon dioxide (Forster et al. 2007). The biogas generated in landfills is 
commonly drained through vertical drain pipes, can be burnt (flaring system) or collected for energy recovery. Even so, in practice, a representative amount of biogas is released through the landfill cover in the form of fugitive emissions (Cabral et al. 2010; Huber-Humer et al. 2008; Staub et al. 2011), which turns the landfill into one of the main anthropogenic sources of greenhouse gases (Mønster et al. 2019; Rose et al. 2012).

Bio-based systems have been used successfully in the reduction of fugitive emissions. The biogas biological oxidation in the landfill cover is a way of mitigating fugitive emissions recognized by the Intergovernmental Panel on Climate Change (IPCC) (Bogner et al. 2007) and it is applicable to both landfills that have some energy recovery technology and smaller or older landfills, where the methane production is too low, which makes its recovery unfeasible (Huber-Humer et al. 2009). In this case, methanotrophic bacteria use methane as carbon and energy sources, transforming it into carbon dioxide, water and biomass (Tanthachoon et al. 2007; Widory et al. 2012). The efficiency of the oxidation process also depends on the choice of suitable substrates, and involves parameters such as porosity, which favors gas exchange and the methane retention time in the substrate, and water retention capacity, since the moisture content promotes the transportation of nutrients to the methanotrophic microorganisms as well as the removal of residues from their metabolic activity (Gebert et al. 2011a; Huber-Humer et al. 2008; Scheutz et al. 2009). Organic matter-rich substrates such as composts (resulting from the decomposition of organic waste), enable the optimization of the oxidation process (Abichou et al. 2009), since in addition to promoting water retention and greater aeration of the medium, they favor microbial growth, $\mathrm{pH}$ neutralization, temperature maintenance, reduction in gas permeability and increase in gas retention time in the landfill cover layer (Huber-Humer et al. 2009; Scheutz et al. 2009).

Several authors have reported the use of compost as alternative substrate aggregated to the soil in the landfill cover as a way of improving methane oxidation. Rose et al. (2012) demonstrated that the use of MSW compost on the landfill cover resulted in increase in the methane oxidation rate with efficiency between $93-97 \%$, when compared to the $67 \%$ efficiency when landfill soil was used. Lee et al. (2018) employed the pilot-scale biocover with landfill cover soil, perlite, earthworm cast, and MSW compost, at a 6:2:1:1 ratio, respectively, and obtained a 35-43\% methane removal efficiency during the winter; while in the summer, this efficiency increased to $86-96 \%$. Franqueto et al. (2019) evaluated two experimental passive methane oxidation biosystems (PMOB's): an enriched subarea (using compost to obtain an organic matter content equal to $4.5 \%$ at the top of the cover layer) and a control subarea (using original landfill cover soil, with an organic matter content equal to $0.4 \%$ ). They observed a higher methane oxidation efficiency in the enriched surface subarea (80\%) when compared to the control (42\%). Maanoja and Rintala (2018) compared the use of inorganic fertilization, decompaction and amelioration of the soil with compost in the cover layer to evaluate the methane mitigation capacity; among the methods under evaluation, compost showed to be the most efficient.

Apart from parameters such as nutrient content, porosity, $\mathrm{pH}$, moisture content and temperature of the medium, the literature also shows the use of higher inlet loadings in biocovers might make the methane oxidation more efficient. Cabral et al. (2010) used a biocover with a substrate layer (mixture of mature compost and sand, at a 5:1 ratio, respectively, and $20 \%$ organic matter content) in a 5-year-old cell in a 
Canadian landfill using biogas from one of the vertical drain pipes. During the study period, the methane loading ranged from 9.3 to $820 \mathrm{~g}_{\mathrm{CH} 4} \cdot \mathrm{m}^{-2} \cdot \mathrm{d}^{-1}$. Their results showed an increase in the methane removal rate with the increasing loading, with approximately $100 \%$ efficiency using the maximum load. Mei et al. (2015) used two cells in a landfill in California to simulate biocovers with green wastes (coming from tree pruning and hoeing), both aged (biocover 1 ) and fresh (biocover 2), with an average organic matter content of 38 and $61 \%$, respectively. The landfill biogas was injected in each cell under an initially lower methane load (110-280 $\left.\mathrm{g}_{\mathrm{CH} 4} \cdot \mathrm{m}^{-2} \cdot \mathrm{d}^{-1}\right)$ and, later on, a higher load was applied (340-660 $\left.\mathrm{g}_{\mathrm{CH} 4} \cdot \mathrm{m}^{-2} \cdot \mathrm{d}^{-1}\right)$. With the load increase, the methane oxidation rate raised, around $17.5 \%$ and $57.7 \%$ in biocovers 1 and 2 , respectively.

In such scenario, this study aimed to compare two experimental passive methane oxidation biocovers (PMOB's), under normal and improved conditions, using compost as aggregate to the landfill original soil, in field columns test (biofilters) applying high biogas loading. Field studies provide a better diagnosis of the methanotrophic population to the variations in working conditions (moisture, temperature, changes in biogas flow rate, methane concentration alterations, abiotic variations, etc.) (La et al. 2018) when compared to laboratory studies (therefore, under controlled conditions). It seems relevant to highlight that great part of the field studies employing biosystems to methane reduction in cover layers are performed in temperate climate countries and, therefore, in ambient conditions completely different than those observed in warm climate countries like Brazil. In addition, the implementation of biotic-systems in landfills without any type of biogas collection becomes a great challenge, since fugitive emissions by the cover layer tend to become even greater when compared to landfills that have some biogas collection system (Franqueto et al. 2019).

\section{Materials And Methods}

\section{Characterization of the study area and preparation of field-columns}

The study was developed at the Municipal Landfill of Guarapuava, in the South of Brazil. A characterization of the waste composition carried out in 2013 resulted in $40 \%$ organic matter, 38\% recyclable material and $22 \%$ non-recyclable material (Guarapuava 2017). The experiment consisted of two columns made of stainless steel, measuring $60 \mathrm{~cm}$ diameter and $100 \mathrm{~cm}$ height, which were coated with a $\cong 20 \mathrm{~cm}$ soil layer used as the system thermal isolation. In order to evaluate the performance of the two biocovers as filtering media, the control column (C) was filled up with a $60 \mathrm{~cm}$ layer of the landfill original soil (sandy clayey silt, with low organic matter content, $\cong 0.8 \%$ ); while the enriched column (E) was filled up with a (bottom) layer of $45 \mathrm{~cm}$ of the landfill original soil and $15 \mathrm{~cm}$ of a mixture containing cover soil (10\%) plus compost (90\%) ( $\cong 6 \%$ final organic matter) on the top layer. The cover layer adopted in this study followed the standards set forth in the Brazilian standard NBR 13.896/1997 (ABNT 1997) and regulations by the environmental agency of the state of Minas Gerais (FEAM 2006). Both layers were deposited on a stainless-steel mesh, so that the biogas distribution through the filter beds could be improved. Biogas was passively captured from a vertical drain pipe (a 4-year-old cell) and injected into the base of the columns with an average flow rate of 500 $\mathrm{mL} \cdot \mathrm{min}^{-1}$ (measured with a bubble flowmeter) in upward flow mode, which corresponded to a $1000 \mathrm{~g} \cdot \mathrm{m}^{-2} \cdot \mathrm{d}^{-1}$ methane inlet loading, at standard temperature and pressure (STP) conditions. The flow rate was periodically measured and adjusted whenever necessary. Figure 1 shows the experiment. 
After preparing the two columns, a period of microbial acclimatation of around 30 days was adopted (under a $1000 \mathrm{~g} \cdot \mathrm{m}^{-2} \cdot \mathrm{d}^{-1}$ loading) prior to the start of the biogas sampling.

\section{Characterization of packing materials and monitoring of columns}

Compost was obtained from a composting plant (Lapa, São Paulo, Brazil) that uses the open market waste (fruit and vegetables) by employing the natural aerated static piles method. The mixture cover soil+compost presented a high final granulometry (Figure 2a), higher than that presented by the landfill original soil (Figure 2b); the compost granulometry was preserved so that the original characteristics of that waste were kept in case it was disposed in the landfill.

Before the experiment start-up, the following parameters of the substrates (enriched and original cover soil) were determined: $\mathrm{pH}$, organic matter content, total carbon, total nitrogen (in the uppermost $0.15 \mathrm{~m}$ of each experimental layer) and porosity. At the end of the experiment, the micronutrients content (zinc, copper, manganese and iron) of the substrates in both columns was also determined (Table 1).

Table 1 Physicochemical parameters of the substrates analyzed in both columns.

\begin{tabular}{cc}
\hline Parameter & Methodology reference \\
\hline $\mathrm{pH}$ & Quaggio and Raij (2001) \\
\hline Organic matter content & Cantarella et al. (2001) \\
\hline Micronutrient content & Abreu et al. (2001) \\
\hline Total nitrogen & Cantarella and Trivelin (2001) \\
\hline Porosity & Donagema et al. (2011) \\
\hline Total carbon & Walkley and Black (1934) \\
\hline
\end{tabular}

In each campaign, the moisture content of the substrates in both columns was determined (sensors Decagon ECH2O CE-5, installed $15 \mathrm{~cm}$ high in each cover layer), as well as temperatures of filter beds, headspace of the columns (Figure 1) and average of ambient temperatures (on the day of the campaign) and punctual (measured only during the sampling time). It seems relevant to highlight that the control and enriched columns were kept in a covered place throughout the whole experiment to prevent the influence of rain; every fortnight, on average, the filtering media were humidified manually by the top of the biofilters, so that the minimum levels of moisture needed for the microbiological activity and to prevent the formation of cracks or fissures (preferential flow paths for biogas release) were kept.

Ten campaigns were carried out from September 2019 to March 2020. The raw biogas was collected from the base of the columns. The determination of the vertical concentration profiles of biogas at different depths of the control and enriched beds was carried out through the sampling ports (stainless-steel tubes with rubber septa) distributed at each $15 \mathrm{~cm}$ along the two filter beds ( $C$ and $E$ ) (Figure 1). Gas sampling was carried out to determine the global efficiency of both biotreatment systems after closing the upper part of the columns (columns headspace); the samples were only collected after the atmospheric air purge in the headspace and the achievement of the steady state. Samples were collected in $60 \mathrm{~mL}$ syringes and injected 
into the Columbus automatic analyzer (Columbus Instruments, EUA) in order to determine methane $\left(\mathrm{CH}_{4}\right)$ and carbon dioxide $\left(\mathrm{CO}_{2}\right)$ concentrations.

\section{Determination of the methane oxidation efficiency in the columns}

To estimate the methane oxidation efficiency, the method proposed by Gebert et al. (2011b) was used, which assumes, among other considerations, that:

- $1 \mathrm{~mol} \mathrm{CH}_{4}$ oxides at $1 \mathrm{~mol} \mathrm{CO}_{2}$;

- carbon dioxide is produced only by methane oxidation; this is assumed for systems that operate with high methane loading and oxidation rates;

- the size of the methanotrophic community is stable;

- the carbon dioxide gas and liquid phases remain in equilibrium;

- the method does not depend on the nature of the flux (diffusive or advective);

- the system operates at steady state. Taking into consideration that the share of oxidized methane can be estimated (Equation 1) and, later on, the methane oxidation efficiency ( $\left.E f_{\text {oX }}\right)$ at different points (depths) of the biofilters can be evaluated (Equation 2) (Gebert et al. 2011b).

Equation 1:

$$
\frac{\mathrm{CO}_{2_{-} L F G}+x}{\mathrm{CH}_{4 \_} \mathrm{LFG}}-x=\frac{\mathrm{CO}_{2_{-} i}}{\mathrm{CH}_{4_{-} i}}
$$

Equation 2:

$$
E f_{o x}=\frac{x}{C H_{4 L F G}} \times 100
$$

Where: $\mathrm{x}=$ share of oxidized $\mathrm{CH}_{4}$ (\%vol.), $\mathrm{CH}_{4 \_ \text {LFG }}=\mathrm{CH}_{4}$ concentration of the raw biogas (vol.\%), $\mathrm{CO}_{2} \_\mathrm{LFG}$ $=\mathrm{CO}_{2}$ concentration of the raw biogas (vol.\%), $\mathrm{CH}_{4} \mathrm{i}=\mathrm{CH}_{4}$ concentration in depth "i" (vol. \%), $\mathrm{CO}_{2} \_\mathrm{i}=\mathrm{CO}_{2}$ concentration in depth " ${ }^{i}$ (vol.\%), depth ${ }^{\prime \prime}{ }^{\prime \prime}=$ four sampling points along the filter beds, spaced at each $15 \mathrm{~cm}$ (Figure 1).

The methane oxidation efficiency ( $g l o b a l-\mathrm{Ef}_{\mathrm{ox}}$ ) was calculated taking into consideration the methane concentrations at the entrance and exit of the filter beds, according to Equation 3 (Fedrizzi et al. 2018).

Equation 3:

$$
\mathrm{Ef}_{\text {ox }}=\frac{\left(\mathrm{C}_{\text {in }}-\mathrm{C}_{\text {out }}\right)}{\mathrm{C}_{\text {in }}} \times 100(\%)
$$

Where: $\mathrm{C}_{\text {in }}=$ methane concentration at the column entrance $(\%)$,

$\mathrm{C}_{\text {aut }}=$ methane concentration at the column exit $(\%)$

\section{Statistical analysis}


To test the hypotheses that temperature and soil moisture influence the methane oxidation process and that the enriched column presents greater oxidation efficiency, data were evaluated in a multivariate way using the cluster analysis, more specifically hierarchical clustering, from the Euclidean distance and single linkage. Later on, to confirm the groupings found in the cluster, the average of variables "methane oxidation (global) efficiency", "moisture content" and "temperature" of filter beds for the levels "control" and "enriched", were contrasted using the t-test and Pearson correlations. The significance level for all analyses was $5 \%$. To verify the assumption of normality, the Anderson Darling test was employed and to check homogeneity of variances the Fligner-Killeen test was used. The result is expressed by the $p$-value $(p<0.05$ indicates statistical difference). The analyses were assisted by the software RStudio, version 4.0.2, packets MASS, cluster and ggplot2 (RStudio 2020).

\section{Results And Discussion}

\section{Characterization of the filter beds}

The analysis of the physicochemical parameters of the substrates in the columns ( $C$ and $E)$ determined at the beginning of the experiment is presented in Table 2.

Table 2 Physicochemical parameters of substrates in columns "control" and "enriched".

\begin{tabular}{|c|c|c|c|c|}
\hline \multirow[b]{3}{*}{ Parameter } & \multicolumn{4}{|c|}{ Column } \\
\hline & \multicolumn{2}{|c|}{ Control } & \multicolumn{2}{|c|}{ Enriched } \\
\hline & Initial & Final & Initial & Final \\
\hline pH & 4.9 & 4.5 & 7.0 & 6.2 \\
\hline Micronutrients - $\mathrm{Zn} / \mathrm{Cu} / \mathrm{Mn} / \mathrm{Fe}\left(\mathrm{mg} \cdot \mathrm{dm}^{-3}\right)$ & \multicolumn{2}{|c|}{$0.7 / 1.3 / 1.1 / 4.0$} & \multicolumn{2}{|c|}{$10 / 3.8 / 43.3 / 73.3$} \\
\hline Carbon (\%) & \multicolumn{2}{|c|}{1.34} & \multicolumn{2}{|c|}{3.50} \\
\hline Nitrogen (\%) & \multicolumn{2}{|c|}{0.08} & \multicolumn{2}{|c|}{0.46} \\
\hline Organic matter content (\%) & \multicolumn{2}{|c|}{0.8} & \multicolumn{2}{|c|}{6.0} \\
\hline Porosity (\%) & \multicolumn{2}{|c|}{80} & \multicolumn{2}{|c|}{95} \\
\hline
\end{tabular}

Table 2 shows that at the beginning of the experiment the enriched column presented more favorable conditions for the development of microorganisms such as methanotrophic bacteria. In the enriched column, $\mathrm{pH}$ values were kept close to neutrality along the whole monitoring period, which tends to favor the methanotrophic communities' performance (Humer and Lechner 1999; Tortora et al. 2012). However, the optimal range of $\mathrm{pH}$ values can vary greatly, depending on factors such as soil type (substrate), biocover depth, and even environmental conditions (Ait-Benichou et al. 2009; Devinny et al. 1999; Huber-Humer et al. 2009; Scheutz et al. 2009), which might explain small variations in the $\mathrm{pH}$ values observed throughout the 6-month monitoring period.

A proper concentration of nutrients (such as nitrogen) in the filter bed is highly relevant for the cell metabolism and the metabolic kinetics of methanotrophic bacteria (Albanna and Fernandes 2009). High nutrient and organic matter contents in the medium are still associated to high methane oxidation rates 
(Abushammala et al. 2014). Regarding nitrogen content, a percentage close to 0.4 is recommended at the start of the process (Devinny et al. 1999), which only occurred in the enriched bed. The literature recommends working with a lower $\mathrm{C} / \mathrm{N}$ ratio so that high methane oxidation rates are obtained (Sadasivam and Reddy 2014). Once again, the $\mathrm{C} / \mathrm{N}$ ratio in the enriched bed was more favorable (7.6) when compared to the control bed (16.8). The substrate organic matter content was higher in the enriched column, which helped water absorption and increased the methane retention time in the filter bed, thus enabling greater dissolved methane availability for the bacteria (Huber-Humer et al. 2008; Humer and Lechner 1999).

The compost addition improved porosity in the upper part of the enriched column, which improved the permeability of the biogas and atmospheric oxygen in the filter bed (Maanoja and Rintala 2018; Scheutz et al. 2009). In addition to the high granulometry of the compost added to the enriched bed (Figure 2), it seems relevant to emphasize that substrates with higher organic matter content are also related to increased porosity in the filter bed (Ait-Benichou et al. 2009). Regarding micronutrients, all the compounds analyzed ( $\mathrm{Zn}, \mathrm{Cu}, \mathrm{Mn}$ and $\mathrm{Fe}$ ) presented much higher concentrations in the enriched column. In fact, the compost addition enriches the filter bed with metal ions, so that the microorganisms are unable to synthesize and use them as cofactor to activate some enzymes for the microbiological development (Tortora et al. 2012). The compost addition is related to the supply of micronutrients and the maintenance of the soil neutrality (Saveyn and Eder 2014).

\section{Raw biogas characterization}

Figure 3 presents the mean values (\%) of methane and carbon dioxide concentrations in the raw biogas throughout the 10 campaigns for the two columns ( $C$ and $E$ ).

The average raw biogas composition was $37.7 \%( \pm 5.5)$ methane and $26.9 \%( \pm 1.7)$ carbon dioxide. Similar results were obtained by Franqueto et al. (2019) in a 4-year-old cell in the same landfill (Guarapuava, Brazil). Figure 3 shows significant variations in the raw biogas composition during the monitoring period. Indeed, the biogas composition might vary greatly, both temporally and spatially, due to the variations in atmospheric and physicochemical conditions (moisture content, temperature, $\mathrm{pH}$, nutrients, pressure, waste composition, etc.) of the waste mass (Farquhar and Rovers 1973; McBean and Farquhar 1980; Rasi et al. 2011). These variations influence directly the microbial activity responsible for the organic matter degradation. In addition, it seems relevant to highlight that the landfill cell used in that study (with 4 years old) was in the anaerobic methanogenic unsteady phase at the time of the monitoring; Augenstein and Pacey (1991) estimated this phase starts between 3 and 5 years after the waste is covered. During this phase, acetic acid, hydrogen and carbon dioxide compounds formed in the previous phases are converted into methane and carbon dioxide; thus, the biogas still presents a heterogeneous composition as shown in Figure 3 (Farquhar and Rovers 1973; O'Leary and Tchobanoglous 2002).

\section{Methane oxidation efficiency in the columns}

Figure 4 presents the methane average oxidation efficiency (\%) throughout the vertical profile of both columns ( $\mathrm{C}$ and $\mathrm{E})$. 
The higher organic matter content (and nutrients) present in the compost promotes an increase in the microbial activity and, consequently, an increase in the methane oxidation (Majdinasab and Yuan 2017). Although the layer that was enriched with compost filled only the upper part of the enriched column (the uppermost $0.15 \mathrm{~m}$ of the enriched layer), Figure 4 shows that the average methane oxidation efficacy of the enriched column was higher than that of the control column throughout the whole vertical profile. As already reported, both filter beds were periodically humified with the same amount of water, in order to keep the minimum levels of moisture needed for the microbiological activity (dry substrate might imply in the inhibition of methanotrophic microorganisms). Since the increase in water was carried out from the top of the columns and in a suitable amount to humify the whole bed, most of the organic matter was carried through the enriched bed, distributing microorganisms and nutrients along the filter bed. In addition, the greatest porosity of the biofilter enriched portion might have provided higher oxygen transfer rates to deeper regions in that column, also resulting in greater methane oxidation in the lower regions of the enriched bed. Indeed, Lopes et al. (2011) verified that compost addition to the landfill soil promoted decrease in grain specific mass and increased soil porosity and permeability; these alterations in the substrate physical characteristics made the medium more suitable for the gaseous exchange and methane oxidation.

The oxidation profiles observed in Figure 4 are in agreement with Cabral et al. (2007), who evaluated a methanotrophic population along the profile of a biocover (mixture of compost and sand at a 5:1 ratio, respectively) and concluded that, in fact, the number of methanotrophic bacteria reduced with depth, and a reduction in the oxidation efficiency was seen with the depth of the cover layer. In addition, Hu and Long (2016) and Thomasen et al. (2019) also reported that greater oxidation efficiencies were seen in the biocover upper layers, since methanotrophic bacteria are aerobic and need atmospheric oxygen to carry out the methane oxidation.

Figure 5 presents the overall oxidation efficiency of methane, moisture content and soil temperature in the columns $\mathrm{C}$ and $\mathrm{E}$, as well as the average ambient temperature (on the day of the campaign - Tenvir $\mathrm{d}_{\text {day }}$ ) and punctual (only measured during the sampling period - Tenvir $r_{\text {punctual }}$ ).

Figure 5 shows that the overall oxidation efficiency of methane was significantly higher ( $t=-8.86, p$-value $<0.01$ ) in the enriched column in all campaigns (average "95\%) when compared to the control column (average »71\%). The greater oxidation capability of the enriched layer with compost (and, therefore, with greater organic matter content in relation to the control layer) is also due to the compost greater water retention capacity. Indeed, the average moisture content in the enriched column was higher ( $t=-3.41, p$-value $<0.01$ ) than that in the control column in all campaigns, with an average of $» 48 \%$ in the enriched column and $» 40 \%$ in the control column. These moisture conditions enable greater diversity of methanotrophic bacteria (not evaluated in the context of this study) that require water to dissolve the nutrients and carry out most of the chemical reactions, such as synthesis and digestive processes (Ait-Benichou et al. 2009; Tortora et al. 2012); this hypothesis was confirmed by the cluster analysis, which is graphically represented in Figure 6 (heatmap).

Considering the ambient temperatures (average and punctual), only Tenvir ${ }_{\text {day }}$ presented significant correlations with the temperature of the control (Tenvir.day with $p=0.02$ and Tenvir.punctual with $p=0.11$ ) and 
enriched columns (Tenvir. day with $p=0.01$ and Tenvir. punctual $_{\text {with }} p=0.7$ ), which evidenced the efficacy of the thermal isolation used in the experiment. It seems relevant to emphasize that the ambient temperatures did not influence significantly the oxidation efficiencies in neither of the columns (control column: Tenvir.day with $p=0.21$ and Tenvir. punctual $_{\text {with }} p=0.6$; enriched column: Tenvir. day $_{\text {with }} p=0.21$ and Tenvir. punctual $_{\text {with }}$ $\mathrm{p}=0.6)$. However, in all campaigns, the average temperature of the substrate in the enriched column $\left(» 29^{\circ} \mathrm{C}\right)$ was statistically higher $(\mathrm{t}=-4.08$; $\mathrm{p}$-value $<0.01)$ than that of the control column $\left(» 23^{\circ} \mathrm{C}\right)$. Cabral et al. $(2010)$ reported that the temperature inside the biocovers is the result of a combined effect of the biogas heat formed during the waste mass decomposition and the heat resulting from the substrate biological oxidation. In this study, both columns were fed simultaneously with biogas from the same vertical drain (at the same temperature); thus, the higher temperature observed in the enriched column is due to the more intense biological oxidation in this medium and, therefore, most of the heat was released during this process (methane oxidation is an exothermic process). This higher temperature $\left(" 29^{\circ} \mathrm{C}\right)$ lied in the range reported by the literature $\left(25-40^{\circ} \mathrm{C}\right)$ as the most favorable to the growth of microorganisms and maintenance of the medium chemical reactions (Devinny et al. 1999; Tortora et al. 2012). This might have been another reason for the overall methane oxidation efficiency being higher in the enriched column when compared to that of the control column, a hypothesis confirmed by the analysis shown in Figure 6 . Figures 3 and 5 also show that the methane oxidation efficiency was not related to its concentration in the raw biogas.

Figure 6 shows that soil moisture, soil temperature and the methane oxidation efficiency formed a group (cluster 2); such grouping is due to the similarity of behavior of these variables, while the punctual and average temperatures on the campaign day formed another cluster (cluster 1). Apart from moisture, the highest organic matter content of the enriched substrate is related to a higher nutrient content available for the microbial growth (Majdinasab and Yuan 2017). Indeed, Devinny et al. (1999) and Tortora et al. (2012) reported that the compost has mineral nutrients that enable the protein synthesis, desoxyribonucleic acid (DNA), ribonucleic acid (RNA) and adenosine triphosphate (ATP) by the microorganisms, favoring microbial growth.

Population and economic growth in developing countries has contributed to a considerable increase in the municipal solid waste generation per capita. Also, the gradual substitution of open dumps with engineered landfills boosted by new public policies related to waste management has also demanded the construction of an increasing number of landfills, contributing to the increase in methane emissions (as fugitive emissions) from these plants (IPCC, 2007). In Brazil, for example, the new Solid Waste National Policy implemented in 2010 provides for the gradual elimination of open dumps (Brasil, 2010). In Brazilian landfills (without a biogas collection system) such emissions are even greater, since there is no drainage system (pumping) for the biogas formed inside the waste mass. A report by the Intergovernmental Panel on Climate Change (IPCC, 2007) reported that bio-based systems (as biofilters and biocovers) are "keytechnologies" for GHG management in landfills. The broader context (political and technical) stimulates the adoption of biotic systems to mitigate GHG. It's also relevant to emphasize that solid waste composting is also a globally incentivized technique to treat the biodegradable fraction of the municipal solid waste, since 
results in decreased pollutant organic matter content and reduces considerably the volume of this type of waste in landfills.

Further research on the economic viability of the full-scale application of the biotic system investigated in this study is still required. The biosystem implementation area in the landfill can vary greatly (consequently, its costs). In addition to the implementation costs, maintenance and monitoring costs involved in a largescale project must also be verified. Finally, in addition to the financial issue, we would like to draw attention to the importance of evaluating the influence of other parameters in methane oxidation, such as the presence of vegetation on the biocover surface, and the substrate microbiological analysis (detailed analysis of the microbial population responsible for the methane degradation).

\section{Conclusions}

This study evaluated the methane passive oxidation in fugitive emissions at the municipal landfill in Guarapuava (Paraná State, Brazil) in columns, under two conditions: control (only landfill cover soil, with low organic matter content: @0.8\%) and enriched (cover soil and the mixture cover soil plus compost with $\cong 6 \%$ organic matter at the uppermost part of the layer).

The overall oxidation efficiencies of methane were higher in the enriched column in all campaigns (averages: »95\% and »71\% in enriched and control columns, respectively). The average methane oxidation efficiency along the vertical profile of the two columns was also higher in the enriched column. These results are associated to the more favorable physicochemical conditions for the development of methanotrophic bacteria due to the compost addition such as higher organic matter content (and, therefore, nutrient content available for the microbial activities) and moisture, which remained higher in the enriched column throughout the monitoring period.

The statistical analysis confirmed that a higher organic matter content in the biosystem influences significantly the methane oxidation efficiency. The cluster analysis also confirmed the hypothesis that a filter bed containing higher organic matter content presents higher water retention capacity, as expected in this study. Temperatures (soil and ambient) did not influence significantly the methane oxidation efficiency in any of the columns, which might be ascribed to the efficacy of the thermal insulation used in the biofilters.

Results obtained in this study demonstrated that the use of bio-based systems might reduce significantly methane fugitive emissions even in landfills without any type of biogas recovery system, which occurs in almost all landfills in developing countries. In addition, the use of organic waste (as compost) can also be seen as a low-cost and environmentally-friendly alternative in the mitigation of greenhouse gases from active or closed landfills. The use of biotic systems is still quite incipient in developing countries such as Brazil. Even so, many municipalities already promote the composting of their organic wastes; therefore, the compost that does not meet quality standards to be commercialized and/or used in the soil as farm input could be used, for example, as aggregate in the landfill cover layers. Another benefit of the use of this 
technique is the reduction in the amount of landfill soil used as cover layer, since soil availability in the landfill location is, sometimes, one of the main problems for the companies that manage these plants.

\section{Declarations}

\section{Acknowlegments}

Authors are thankful to the Brazilian Ministry of Education - MEC (scholarship "PET-Engenharias"), to “Coordenação de Aperfeiçoamento de Pessoal de Nível Superior" (CAPES, Grant \#88881.030497/2013-01) and to "Fundação Araucária do Paraná" (Call 09/2016) for the financial support. They also thank the Guarapuava City Hall (Paraná State, Brazil)

Declaration: Authors declare they have no conflicts of interest.

\section{References}

Abichou T, Mahieu K, Yuan L, Chanton J, Hater G (2009) Effects of compost biocovers on gas flow and methane oxidation in a landfill cover. Waste Manag 29:1595-1601.

https://doi.org/10.1016/j.wasman.2008.11.007

Abreu CA, Abreu MF, Andrade JC (2001) Determinação de cobre, ferro, manganês, zinco, cádmio, cromo, níquel e chumbo em solos usando a solução de DTPA em pH 7,3. In: Raij BV, Andrade JC, Cantarella H, Quaggio JA Análise Química para Avaliação da Fertilidade de Solos Tropicais. Campinas (SP, Brasil), pp 240-250 [in Portuguese]

Abushammala MFM, Basri NEA, Irwan D, Younes MK (2014) Methane oxidation in landfill cover soils: a review. Asian J Atmos Environ 08:1-14. https://doi.org/10.5572/ajae.2014.8.1.001

Ait-Benichou S, Jugnia LB, Greer CW, Cabral AR (2009) Methanotrophs and methanotrophic activity in engineered landfill biocovers. Waste Manag 29:2509-2517. https://doi.org/10.1016/j.wasman.2009.05.005

Albanna M, Fernandes L (2009) Effects of temperature, moisture content, and fertilizer addition on biological methane oxidation in landfill cover soils. Pract Period Hazard, Toxic, Radioact Waste Manag 13:187-195. https://doi.org/10.1061/(asce)1090-025x(2009)13:3(187)

Associação Brasileira de Normas Técnicas - ABNT (1997) Aterros de resíduos não-perigosos - Critérios para projetos, implantação e operação. NBR 13.896. [in Portuguese]

Augenstein D, Pacey J (1991) Modelling landfill methane generation. In: Third International Landfill Symposium, Cagliari, Italy, pp 115-148.

Bogner J, Abdelrafie Ahmed M, Diaz C, Faaij A, Gao Q, Hashimoto S, Mareckova K, Pipatti K, Zhang T (2007) Waste management. In: Metz B, Davidson OR, Bosch PR, Dave R, Meyer LA (Eds.) Climate Change 2007: Mitigation. Contribution of Working Group III to the Fourth Assessment Report of the Intergovernmental 
Panel on Climate Change. Cambridge University Press, Cambridge, United Kingdom and New York, USA, pp 585-618

Brasil (2010) Lei n 12.305, de 02 de agosto de 2010. Institui a Política Nacional de Resíduos Sólidos. Diário Oficial da União, Brasília (DF). http://www.planalto.gov.br/ccivil_03/_ato20072010/2010/lei/l12305.htm Acessed 05 May 2021 [in Portuguese]

Cabral AR, Arteaga K, Rannaud D, Ait-Benichou S, Pouët M-F, Allaire S, Jugnia LB, Greer C (2007) Analysis of methane oxidation and dynamics of methanotrophs within a passive methane oxidation barrier. In: Eleventh International Waste Management and Landfill Symposium, Cagliari, Italy.

Cabral AR, Moreira JFV, Jugnia LB (2010) Biocover Performance of Landfill Methane Oxidation: Experimental Results. J Environ Eng 136:785-793. https://doi.org/10.1061/(asce)ee.1943-7870.0000182

Cantarella H, Quaggio JA, Raij BV (2001) Determinação de matéria orgânica. In: Raij BV, Andrade JC, Cantarella H, Quaggio JA Análise Química para Avaliação da Fertilidade de Solos Tropicais. Campinas (SP, Brasil), pp 173-180 [in Portuguese]

Cantarella H, Trivelin PCO (2001) Determinação de nitrogênio total em solo. In: Raij BV, Andrade JC, Cantarella H, Quaggio JA Análise Química para Avaliação da Fertilidade de Solos Tropicais. Campinas (SP, Brasil), pp 262-269 [in Portuguese]

Devinny JS, Deshusses MA, Webster TS (1999) Biofiltration for Air Pollution Control. Boca Raton, CRC Press Lewis Publishers

Donagema GK, Campos DVB, Calderano SB, Teixeira WG, Viana JHM (Org.) (2011) Manual de métodos de análise de solos. Documentos 132. $2^{\mathrm{a}}$ ed. Embrapa Solos, Rio de Janeiro [in Portuguese]

Farquhar CJ, Rovers FA (1973) Gas Production During Refuse Decomposition. Water Air Soil Pollut 2:483495. https://doi.org/10.1007/BF00585092

Fedrizzi F, Cabana H, Ndanga EM, Cabral AR (2018) Biofiltration of methane from cow barns: Effects of climatic conditions and packing bed media acclimatization. Waste Manag 78:669-676.

https://doi.org/10.1016/j.wasman.2018.06.038

Forster P, Ramaswamy V, Artaxo P, Berntsen T, Betts R, Fahey DW, Haywood J, Lean J, Lowe DC, Myhre G, Nganga J, Prinn R, Raga G, Schulz M, Van Dorland R (2007) Changes in atmospheric constituents and in radiative forcing. In: Solomon S, Qin D, Manning M, Chen Z, Marquis M, Averyt KB, Tignor M, Miller HL (Eds.) Climate Change 2007: The Physical Science Basis. Contribution of Working Group I to the Fourth Assessment Report of the Intergovernmental Panel on Climate Change. Cambridge University Press, Cambridge, UK and NY, USA, pp 129-234

Franqueto R, Cabral AR, Capanema MA, Schirmer WN (2019) Fugitive methane emissions from two experimental biocovers constructed with tropical residual soils: field study using a large flux chamber. Detritus 07:119-127. https://doi.org/10.31025/2611-4135/2019.13844 
Fundação Estadual do Meio Ambiente - FEAM (2006) Orientações básicas para a operação de aterro sanitário. Belo Horizonte, 36p. [in Portuguese]

Gebert J, Groengroeft A, Pfeiffer EM (2011a) Relevance of soil physical properties for the microbial oxidation of methane in landfill covers. Soil Biol Biochem 43:1759-1767.

https://doi.org/10.1016/j.soilbio.2010.07.004

Gebert J, Röwer IU, Scharff H, Roncato CDL, Cabral AR (2011b) Can soil gas profiles be used to assess microbial $\mathrm{CH}_{4}$ oxidation in landfill covers? Waste Manag 31: 987-994.

https://doi.org/10.1016/j.wasman.2010.10.008

Guarapuava (2017) Plano municipal de saneamento básico - Município de Guarapuava-PR: diagnóstico e plano de metas.

http://www.concidade.com.br/concidade/download/planos_municipais/Plano_Municipal_de_Saneamento_ Guarapuava_2018_2021_versao_audiencia.pdf Acessed 08 January 2019 [in Portuguese]

Hu L, Long Y (2016) Effect of landfill cover layer modification on methane oxidation. Environ Sci Pollut Res 23:25393-25401. https://doi.org/10.1007/s11356-016-7632-y

Humer M, Lechner P (1999) Alternative approach to the elimination of greenhouse gases from old landfills. Waste Manag Res 17:443-452. https://doi.org/10.1034/j.1399-3070.1999.00064.x

Huber-Humer M, Gebert J, Hilger H (2008) Biotic systems to mitigate landfill methane emissions. Waste Manag Res 26:33-46. https://doi.org/10.1177/0734242X07087977

Huber-Humer M, Röder S, Lechner P (2009) Approaches to assess biocover performance on landfills. Waste Manag 29:2092-2104. https://doi.org/10.1016/j.wasman.2009.02.001

IPCC (2007) Climate Change 2007: Mitigation. Contribution of Working Group III to the Fourth Assessment Report of the Intergovernmental Panel on Climate Change. Metz B, Davidson OR, Bosch PR, Dave R, Meyer LA (ed.), Cambridge University Press, Cambridge, United Kingdom and New York, 851p.

La H, Hettiaratchi JPA, Achari G, Dunfield PF (2018) Biofiltration of methane. Bioresour Technol 268:759772. 10.1016/j.biortech.2018.07.043

Lee YY, Jung H, Ryu HW, Oh KC, Jeon JM, Cho KS (2018) Seasonal characteristics of odor and methane mitigation and the bacterial community dynamics in an on-site biocover at a sanitary landfill. Waste Manag 71:277-286. https://doi.org/10.1016/j.wasman.2017.10.037

Lopes RL, Alves MCM, Jucá JFT (2011) Water infiltration and methane emission through three different cover layers of an experimental municipal waste landfill at Muribeca, Recife-PE-Brazil. In: Fifth International Conference on Unsaturated Soils, Barcelona, Spain, pp 1407-1412.

Maanoja ST, Rintala JA (2018) Evaluation of methods for enhancing methane oxidation via increased soil air capacity and nutrient content in simulated landfill soil cover. Waste Manag 82:82-92. 
https://doi.org/10.1016/j.wasman.2018.10.015

Majdinasab A, Yuan Q (2017) Performance of the biotic systems for reducing methane emissions from landfill sites: A review. Ecol Eng 104:116-130. https://doi.org/10.1016/j.ecoleng.2017.04.015

McBean EA, Farquhar GJ (1980) An Examination of Temporal/Spatial Variations in Landfill-Generated Methane Gas. Water Air Soil Pollut 13:157-172. https://doi.org/10.1007/BF02279543

Mei C, Yazdani R, Han B, Mostafid ME, Chanton J, Vandergheynst J, Imhoff P (2015) Performance of green waste biocovers for enhancing methane oxidation. Waste Manag 39:205-215.

https://doi.org/10.1016/j.wasman.2015.01.042

Mønster J, Kjeldsen P, Scheutz C (2019) Methodologies for measuring fugitive methane emissions from landfills - A review. Waste Manag 87:835-859. https://doi.org/10.1016/j.wasman.2018.12.047

O'Leary PR, Tchobanoglous G (2002) Landfilling. In: Tchobanoglous G, Kreith F Handbook of Solid Waste Management. McGraw-Hill Companies, $2^{\text {nd }}$ ed., pp 14.1-14.93

Quaggio JA, Raij BV (2001) Determinação do pH em cloreto de cálcio e da acidez total. In: Raij BV, Andrade JC, Cantarella H, Quaggio JA Análise Química para Avaliação da Fertilidade de Solos Tropicais. Campinas (SP, Brasil), pp 181-188 [in Portuguese]

Rasi S, Läntelä J, Rintala J (2011) Trace compounds affecting biogas energy utilisation - A review. Energy Convers Manage 52:3369-3375. https://doi.org/10.1016/j.enconman.2011.07.005

Rose JL, Mahler CF, Izzo RLS (2012) Comparison of the methane oxidation rate in four media. Rev Bras Ciênc Solo 36:803-812. https://doi.org/10.1590/S0100-06832012000300011

RStudio Team (2020). RStudio. Integrated Development for R. RStudio, PBC, Boston, MA. http://www.rstudio.com/

Sadasivam BY, Reddy KR (2014) Landfill methane oxidation in soil and bio-based cover systems: a review. Rev Environ Sci Biotechnol 13:79-107. https://doi.org/10.1007/s11157-013-9325-z

Saveyn H, Eder P (2014) End-of-waste criteria for biodegradable waste subjected to biological treatment (compost \& digestate): Technical proposals. European Commission, Joint Research Centre, Scientific and Policy Reports, Sevilla (Spain)

Scheutz C, Kjeldsen P, Bogner JE, De Visscher A, Gebert J, Hilger HA, Huber-Humer M, Spokas K (2009) Microbial methane oxidation processes and technologies for mitigation of landfill gas emissions. Waste Manag Res 27:409-455. https://doi.org/10.1177/0734242X09339325

Staub MJ, Marcolina G, Gourc JP, Simonin R (2011) An incremental model to assess the environmental impact of cap cover systems on MSW landfill emissions. Geotext Geomembr 29:298-312. https://doi.org/10.1016/j.geotexmem.2011.01.013 
Tanthachoon N, Chiemchaisri C, Chiemchaisri W (2007) Alternative Approach for Encouraging Methane Oxidation in Compost Based Landfill Cover Layer with Vegetation. In: Proceedings of the International Conference on Sustainable Solid Waste Management, Chennai, India, pp 202-209.

Thomasen TB, Scheutz C, Kjeldsen P (2019) Treatment of landfill gas with low methane content by biocover systems. Waste Manag 84:29-37. https://doi.org/10.1016/j.wasman.2018.11.011

Tortora GJ, Funke BR, Case CL (2012) Microbiologia. Tradução: Aristóbolo Mendes da Silva [et al.]; Revisão técnica: Flávio Guimarães da Fonseca. $10^{\mathrm{a}} \mathrm{ed}$. Artmed, Porto Alegre [in Portuguese]

Walkley A, Black IA (1934) An examination of the Degtjareff method for determining soil organic matter and a proposed modification of the chromic acid titration method. Soil Sci 37:29-38.

https://doi.org/10.1097/00010694-193401000-00003

Widory D, Proust E, Bellenfant G, Bour O (2012) Assessing methane oxidation under landfill covers and its contribution to the above atmospheric $\mathrm{CO}_{2}$ levels: The added value of the isotope $\left(\delta^{13} \mathrm{C}\right.$ and $\delta^{18} \mathrm{O} \mathrm{CO}_{2} ; \delta^{13} \mathrm{C}$ and $\delta \mathrm{D} \mathrm{CH}_{4}$ ) approach. Waste Manag 32:1685-1692. https://doi.org/10.1016/j.wasman.2012.04.008

\section{Figures}

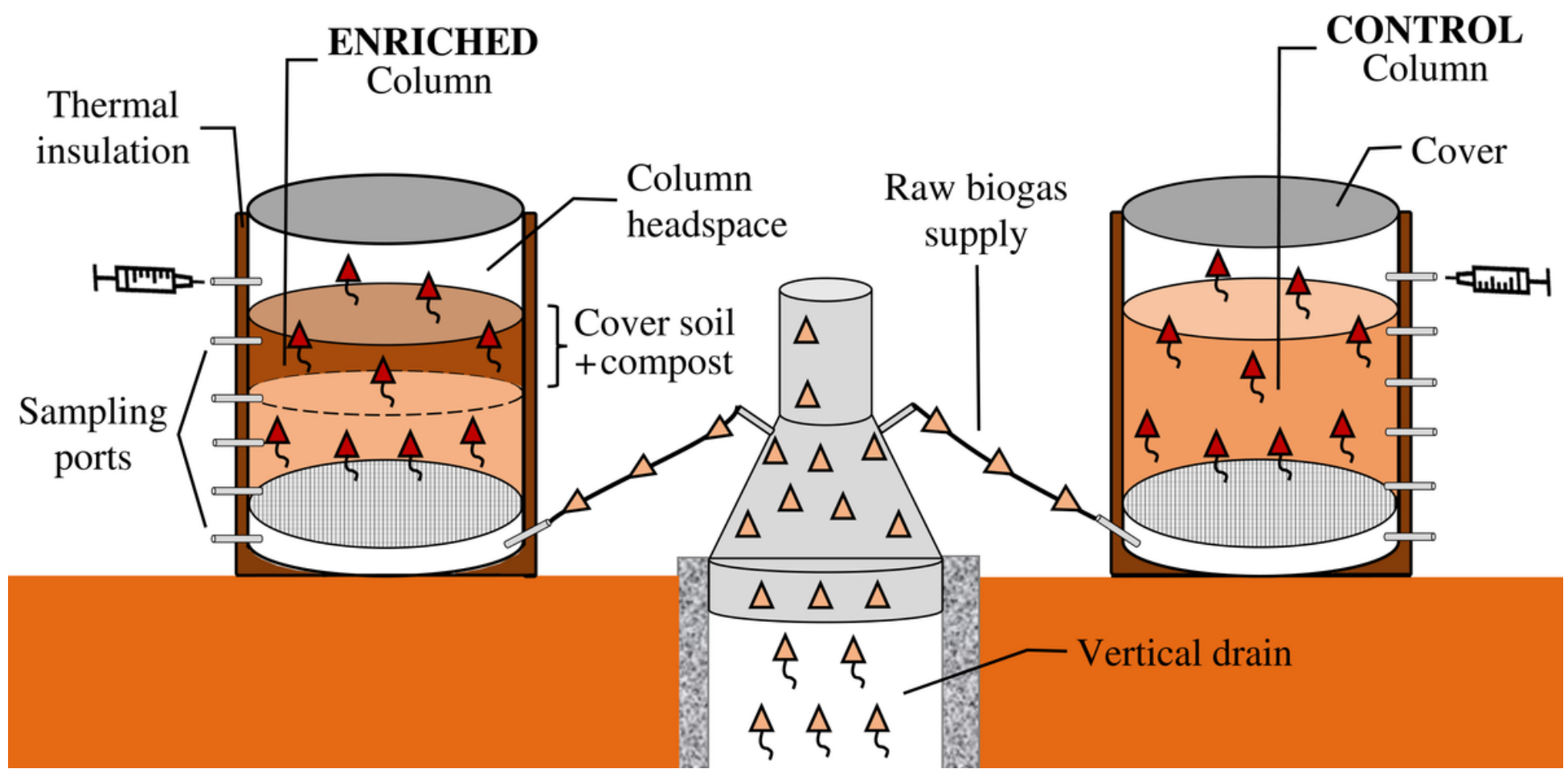

Figure 1

Scheme of capture and injection of biogas into the two columns (control and enriched). 

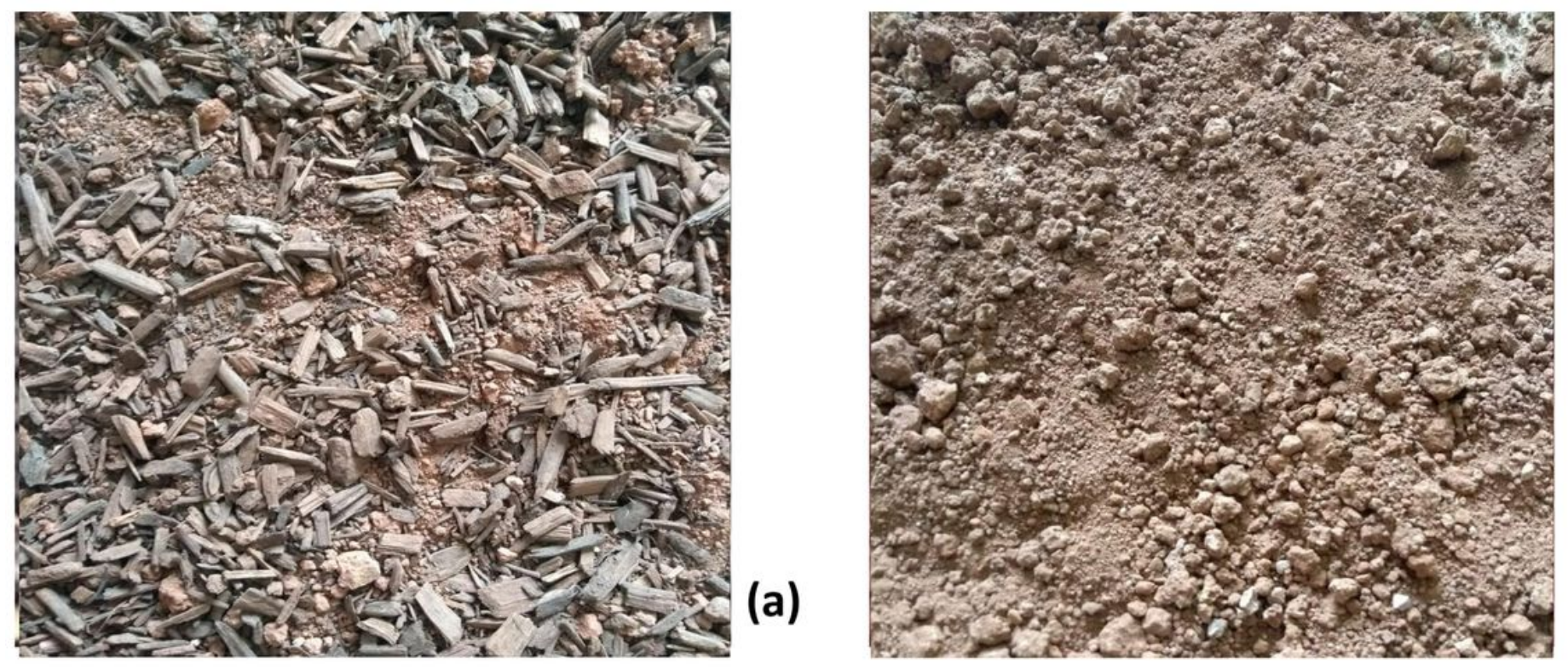

(b)

Figure 2

Packing materials: (a) enriched and (b) control.

50

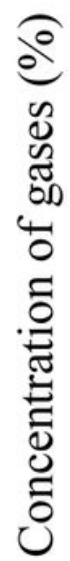

45
40
35
30
25
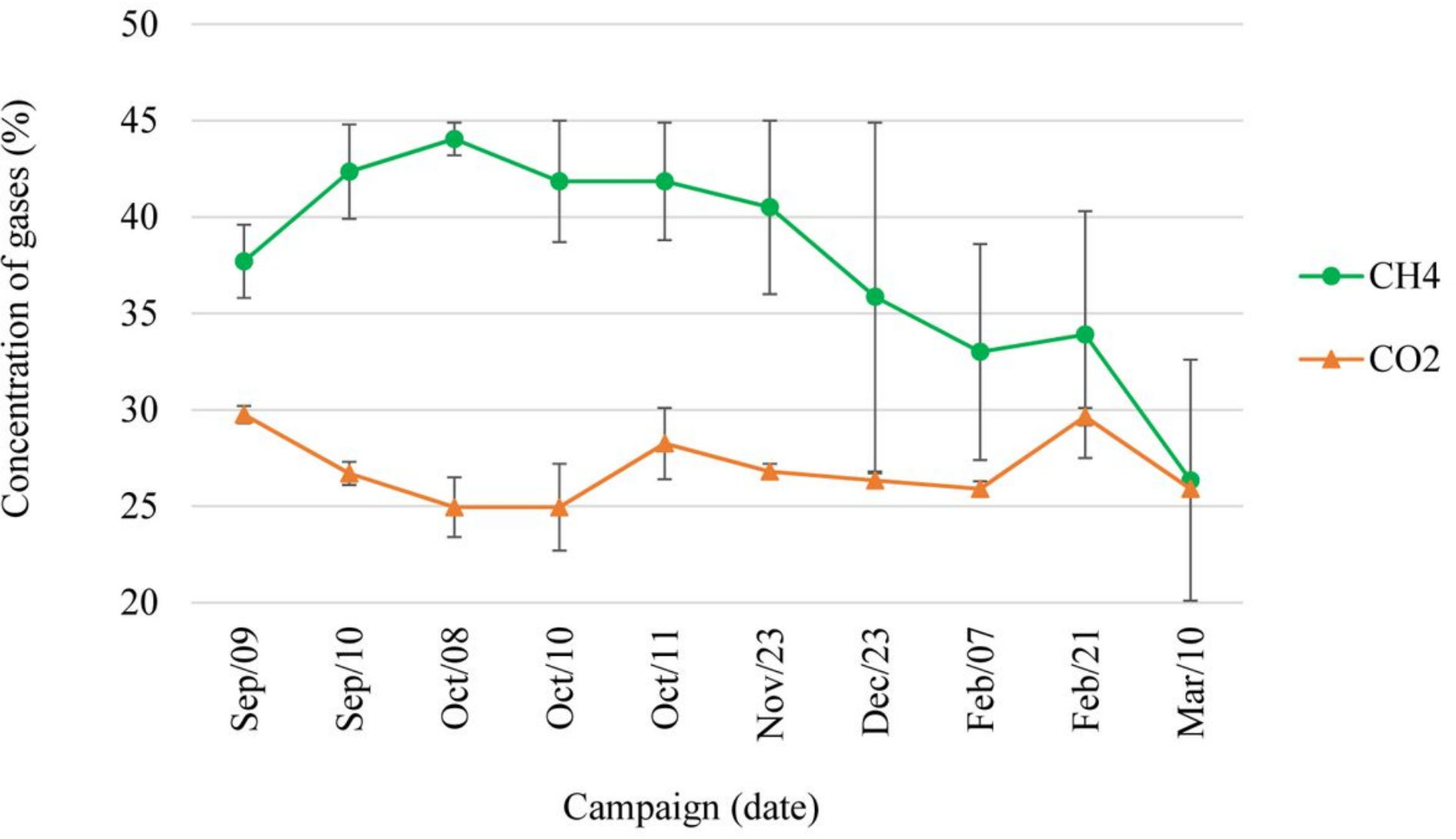

(a)

Figure 3

Average composition (and standard error) of raw biogas at the entrance of the control and enriched column 


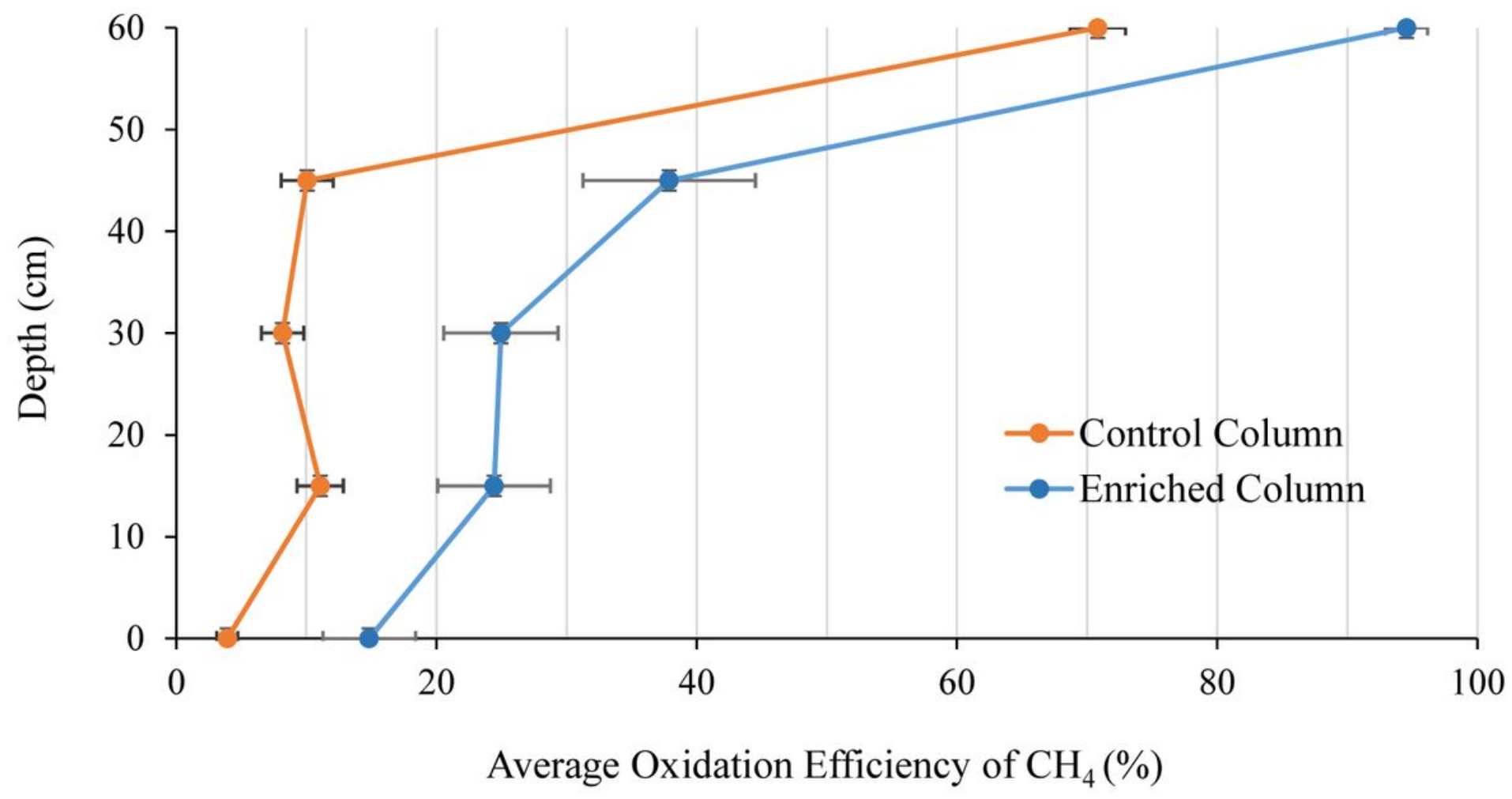

Figure 4

Methane oxidation (\%) (and standard error) throughout the vertical profile of columns C and $\mathrm{E}$.

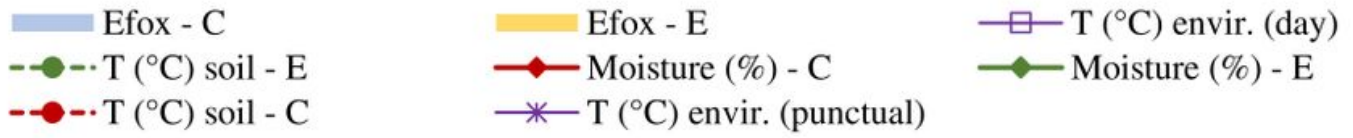

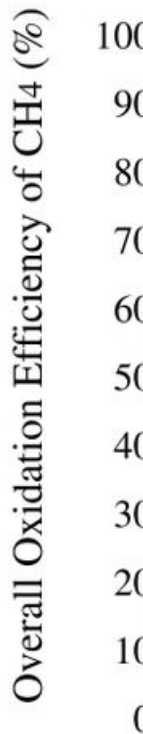
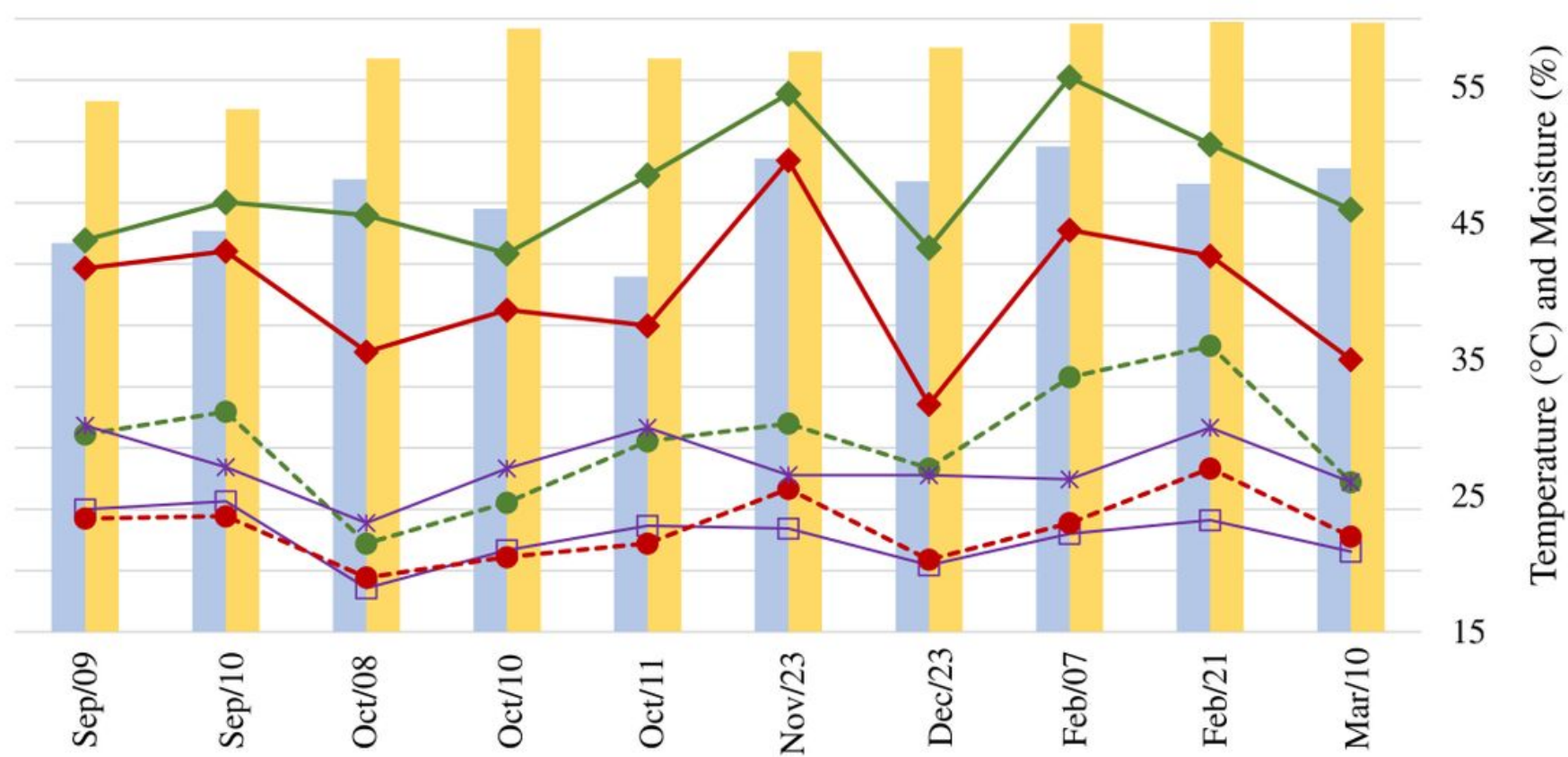

Campaign (date) 


\section{Figure 5}

Monitoring of the methane oxidation global efficiency in the control (Efox-C) and enriched (Efox-E) columns.

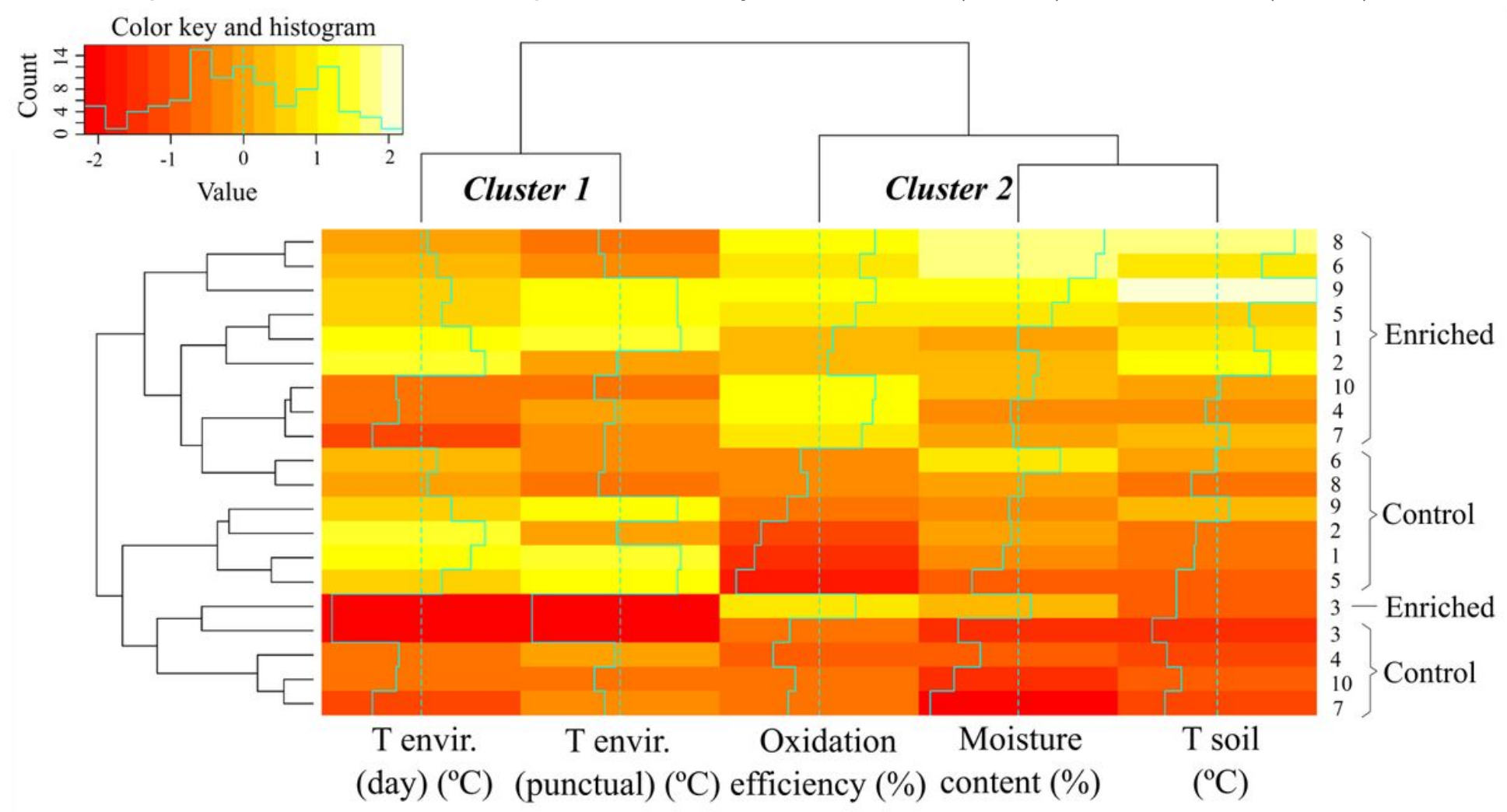

\section{Figure 6}

Cluster analysis for the monitoring of control and enriched columns.

\section{Supplementary Files}

This is a list of supplementary files associated with this preprint. Click to download.

- GraphicalAbstract.jpg 